\title{
Post War Media Behavior in Sri Lanka
}

Krishan Jayashanka Siriwardhana*

Journalism Unit, University of Colombo, Sri Lanka

\begin{abstract}
Three decades of civil war which was recently ended in Sri Lanka can be considered as one of the most brutal conflicts in the Asian region. The content of the both electronic and print media in Sri Lanka have been dominated with the war related information during the past three decades. Especially, during the final stages of the war there was no notable space for other information as everything was written and reported on war. There was a clearly visible competition among national newspapers to attract the readership with content of war. Since the end of the war, newspapers found it difficult to keep their readers with ordinary news and they started reporting crimes and other sensitive incidents to attract readers. This paper discuses the post war media behavior in Sri Lanka with special reference to National newspapers in the country. Discourse analysis is conducted on four selected newspapers representing both government and private sector newspapers. As the war ended in may 2009, the study is conducted on randomly selected newspapers from January 2010 to March 2012. The analysis is limited to the news content in the front pages of the newspapers. Though there are many studies have been conducted on the media behavior during the war, there is no study has been done to examine the significances of the post war media behavior in the country and also no recent study has been done in the region regarding post conflict media behavior. The research is conducted with the hypotheses that the newspapers have exaggeratedly reported crimes to catch readers. Though the initial study clearly indicates the domination of crime related content in newspapers, the research aims to identify whether there is an increase in the crimes in the country as the media reported or it is an exaggeration created by media in the post war context.
\end{abstract}

\section{Introduction and Background}

Sri Lanka is a country off the southern coast of the Indian subcontinent with an approximate population of 20 million. Liberation Tigers of Tamil Eelam (LTTE) had been fighting to create a separate Tamil Eelam state in the North and East of the country for three decades. Various Sri Lankan governments made efforts to solve the issue with peace talks and also with military campaigns. United Peoples Freedom Alliance government (UPFA) which came to power in 2005 decided to start a military campaign against LTTE and it was ended in 2009 after government troops captured the whole north and east parts of the country. According to the defense ministry of Sri Lanka (2009) [1] 6200 government security personnel were killed in the final stages of the war from 2006 to 2009. South Asian Terrorism Portal (2009) [2] states that 5241 government soldiers and 21953 LTTE cadres were killed in the war. Unlike other war times, from 2006 to 2009 is quite significant as the whole country was under a war mentality and the both electronic and print media had given priority to the war reporting.

Electronic and Print media industry in Sri Lanka is owned by both state and private sector companies. As the study is focused on the role of newspapers since the war ended, it is quite necessary to see the expansion of the newspaper industry in the country.

\section{Newspaper Industry in Sri Lanka}

\begin{tabular}{|l|l|l|l|}
\hline Newspaper & Ownership & Frequency & $\begin{array}{l}\text { Approximate } \\
\text { circulation }\end{array}$ \\
\hline Daily mirror -(English) & $\begin{array}{l}\text { Wijeya Newspapers } \\
\text { Limited (private) }\end{array}$ & Daily & 25,000 \\
\hline DailyNews -(English) & $\begin{array}{l}\text { Associated News- } \\
\text { papers of Ceylon } \\
\text { Limited (government) }\end{array}$ & Daily & 88,000 \\
\hline The Island-(English) & $\begin{array}{l}\text { Upali Newspapers Ltd } \\
\text { (private) }\end{array}$ & Daily and weekly & $\begin{array}{l}\text { Daily- 70,000 } \\
\text { Week- } \\
\text { ly-103,000 }\end{array}$ \\
\hline Ceylon Today -(English) & $\begin{array}{l}\text { Ceylon Newspapers } \\
\text { (private) }\end{array}$ & $\begin{array}{l}\text { Daily and } \\
\text { Sunday }\end{array}$ & No data \\
\hline $\begin{array}{l}\text { The Sunday Leader- } \\
\text { (English) }\end{array}$ & $\begin{array}{l}\text { Leader Publications } \\
\text { Ltd (private) }\end{array}$ & Weekly & No data \\
\hline
\end{tabular}

\begin{tabular}{|c|c|c|c|}
\hline $\begin{array}{l}\text { Sunday Observer-(Eng- } \\
\text { lish) }\end{array}$ & $\begin{array}{l}\text { Associated News- } \\
\text { papers of Ceylon } \\
\text { Limited (government) }\end{array}$ & Weekly & 175,000 \\
\hline $\begin{array}{l}\text { The Sunday Times- } \\
\text { (English) }\end{array}$ & $\begin{array}{l}\text { Wijeya Newspapers } \\
\text { Limited ( private) }\end{array}$ & Weekly & 330,000 \\
\hline The Nation & $\begin{array}{l}\text { Rivira Media Corpora- } \\
\text { tions (private) }\end{array}$ & Weekly & 132,000 \\
\hline $\begin{array}{l}\text { Lakbima News-(Eng- } \\
\text { lish) }\end{array}$ & $\begin{array}{l}\text { Sumathi Newspapers } \\
\text { Ltd (private) }\end{array}$ & Weekly & No data \\
\hline Dinamina-(Sinhala) & $\begin{array}{l}\text { Associated News- } \\
\text { papers of Ceylon } \\
\text { Limited (government) }\end{array}$ & Weekly & 75,000 \\
\hline Divaina- Sinhala & $\begin{array}{l}\text { Upali Newspapers Ltd } \\
\text { (private) }\end{array}$ & Daily and Weekly & $\begin{array}{l}\text { Daily-156,000 } \\
\text { Week- } \\
\text { ly-340,000 }\end{array}$ \\
\hline Lakbima-Sinhala & $\begin{array}{l}\text { Sumathi Newspapers } \\
\text { Ltd (private) }\end{array}$ & Daily and Weekly & No data \\
\hline Lankadeepa-Sinhala & $\begin{array}{l}\text { Wijeya Newspapers } \\
\text { Limited ( private) }\end{array}$ & Daily and Weekly & $\begin{array}{l}\text { Daily-150,000 } \\
\text { Week- } \\
\text { ly-350,000 }\end{array}$ \\
\hline Rivira- Sinhala & $\begin{array}{l}\text { Rivira Media Corpora- } \\
\text { tions (private) }\end{array}$ & Daily and Weekly & $\begin{array}{l}\text { Weekly } \\
-265,000\end{array}$ \\
\hline Mawbima-Sinhala & $\begin{array}{l}\text { Ceylon Newspapers } \\
\text { (private) }\end{array}$ & Daily and weekly & No data \\
\hline Sudar Oli-Tamil & $\begin{array}{l}\text { Uthayan Group of } \\
\text { Newspapers- (pri- } \\
\text { vate) }\end{array}$ & Daily & No data \\
\hline
\end{tabular}

*Corresponding author: Krishan Jayashanka Siriwardhana, Journalism Unit, University of Colombo, Sri Lanka, E-mail: raseemadu@yahoo.com

Received September 18, 2012; Accepted October 27, 2012; Published November 06, 2012

Citation: Siriwardhana KJ (2012) Post War Media Behavior in Sri Lanka. J Mass Commun Journalism 2:127. doi:10.4172/2165-7912.1000127

Copyright: (c) 2012 Siriwardhana KJ. This is an open-access article distributed under the terms of the Creative Commons Attribution License, which permits unrestricted use, distribution, and reproduction in any medium, provided the original author and source are credited. 


\begin{tabular}{|l|l|l|l|}
\hline Thinakaran-Tamil & $\begin{array}{l}\text { Associated News- } \\
\text { papers of Ceylon } \\
\text { Limited (government) }\end{array}$ & Daily & 50,000 \\
\hline Thinakkural-Tamil & $\begin{array}{l}\text { Thinakkural Publica- } \\
\text { tions Ltd (private) }\end{array}$ & Daily & No data \\
\hline Uthayan-Tamil & $\begin{array}{l}\text { Uthayan Group of } \\
\text { Newspapers }\end{array}$ & Daily & No data \\
\hline Virakesari-Tamil & $\begin{array}{l}\text { Express Newspapers } \\
\text { (Ceylon) (Pvt) Ltd }\end{array}$ & Daily & 140,000 \\
\hline
\end{tabular}
report.

${ }^{\star}$ the circulation statistics is based in 2009 newspaper circulation

Newspapers are published Sinhala, Tamil and English languages in the country and there is an increase in the number of newspapers in the country since the end of the war.

Kieran [3] argues that one of the functions the media must fulfill is to report and evaluate appropriately events that affect our lives as members of society. In the war times media has a big role to play in reporting the incidents which are taking place with immense impact on human lives. The role media played during the war doesn't end even if the war is ended. Media needs to play a critical role in post war context as the behavior of the media has a quite significant impact on post war societies [4].

\section{Objectives of the Study}

The main objective of the study is to identify the representation of war in Sri Lankan national newspapers in post war context.

The general objectives of the study are to identify the dominant news items which filled the newspapers after the end of war. The study also intends to examine the presentation of crime news in the post war context and its signifances with the crime reporting during war time.

\section{Research Methodology}

Both qualitative and quantitative methods are used in the study as statistical data collected and analyzed for selected newspaper articles, and content of the news is discussed in a qualitative perspective. A discourse analysis of selected newspapers from January 2010 to April 2012 is conducted in this study.

Four national newspapers are selected in the study representing both government and private sector owned media institutions. Island wide circulation and the number of circulations is also taken in to consideration when selecting newspapers for the study. The selected four newspapers are Sinhala and English medium newspapers as Tamil medium paper could not be selected due to researcher's lack of knowledge in Tamil language. It also helps to limit the research area. But overall perspective of Tamil Newspapers has been taken into consideration in the discussion.

Sinhala Language daily Lankadeepa, English language Daily mirror, Sinhala Language weekly Divaina and English Language weekly Sunday Observer newspapers have been selected for the study. The study is limited to study the front page news items of the selected four newspapers.

\section{Analysis and Research Findings}

The study includes 40 randomly selected newspaper front pages from the selected four newspapers.10 papers from one newspapers is taken in the study, ex-10 lankadeepa newspapers, 10 Daily mirror newspapers. Total number of 100 front page news items from each four selected newspapers has been collected in the study.
In the initial stage statistical data is collected on the content of the front page news on selected newspapers.

The war related news means the news items which directly discuss about the war even though it is ended and also the representations of incidents regarding the war. The news items reported on reconciliation

\begin{tabular}{|l|l|l|l|}
\hline Newspaper & $\begin{array}{l}\text { Number of War } \\
\text { Related News }\end{array}$ & $\begin{array}{l}\text { Number of Crime } \\
\text { News }\end{array}$ & Other \\
\hline Lankadeepa & 26 & 51 & 23 \\
\hline Dailymirror & 21 & 41 & 58 \\
\hline Sunday Divaina & 31 & 21 & 48 \\
\hline Sunday Observer & 39 & 16 & 45 \\
\hline
\end{tabular}

and political solution to the ethnic problem is not considered under war and war related news category. The crime news category includes the reporting of crimes during the selected time duration. Other category consists of the development and mainly political news.

According to the collected data significant space is allocated to the war related news in all the selected newspapers since the end of war [5]. The state owned Sunday Observer has reported the most number of war related news items from the selected papers while the Sinhala weekly Divaina has more war related news than Lankadeepa and Daily mirror. On the other hand lankadeepa and Dailymirror which has less number war related news items compared to other two papers presented significantly high number of crime news items than Sunday Island and Sunday Observer. In the "other" category most number of articles were reported by Sunday Observer. Majority of the Sunday Observer news items in this category are about the development projects and programmes initiated by the governments [6]. There is not much difference of the number of news items of "other" category between Lankadeepa, Sunday Divaina and Daily mirror papers. Overall, 117 war related news items appeared in the front pages of selected newspapers while 129 crime news and 174 other news items have been appeared in the selected newspapers.

There are significant differences in the way same news related to war is presented in different newspapers. The news about the white flag issue was reported in Lankadeepa with facts of the incident. On the other hand state owned Sunday Observer had reported the news in a different perspective and it directly criticizes certain parties for making the white flag issue [7]. The Sunday Divaina newspaper reported the same news as it is a threat to the country and empathize the need of being united for the political parties to face the problem.

Though all the selected newspapers had reported war related news after the war ended, there is a significant difference in the way news items have been selected by the media institutions. The state owned Sunday Observer gives prominence to the welfare work done by the government military forces for the war affected people. $40 \%$ of their war related news is about the finding of LTTE arms by the military forces. On the other hand, Lankadeepa gives priority to the various views and opinions of politicians about the resettlement of internally displaced people from the war. The Daily mirror also gives priority in their front page about the views of politicians on the post war resettlements process and reconciliation [8].

From the early 2011 to early 2012 there is a notable increase in the Crime news in Sri Lankan national newspapers. In the first three months of 2011 only $32 \%$ space was allocated to crime news in the selected four newspapers. But in the first quarter of 2012 that has been increased up to $61 \%$. The space dedicated to war related news was given to the crime news and it dramatically increased from 2011 onwards [9]. 
Privately owned Lankadeepa and Daily mirror had reported notably high number of crimes compared to the state owned Sunday Observer and Sunday Divaina. $72 \%$ lead stories of the Lankadeepa are on war related information and crimes while only $13 \%$ crimes news has taken as the lead in Sunday Observer.

\section{Conclusion}

Though the war was ended in 2009, still the mainstream newspapers in the country are allocating significant space for the war related news and state owned newspapers are proving more space compared to others. State owned papers included content on justification to the war the development of war affected lives in North and East.

The Private owned newspapers have given priority to the reporting of crimes and issues with direct social influence. Though there has been an increase in the crimes in the country, the private owned newspapers also have given priority to the reporting of crime news. The reason behind that is to attract and keep the reader with catchy information which the general Sri Lankan reader is used for three decades. During the last four months where the mainstream media has been giving priority to the UN Human Rights Council meeting held in Geneva to discuss the post war reconciliation issues in the country, there is a significant increase in the news items reported on war relation information. Even though it has been three years since the war ended, newspapers are giving priority to war related information while giving comparatively less attention to the political solution to the ethnic problem and also about reconciliation. Newspapers are maintaining the war mentality in the country with the presentation of crimes.

\section{References}

1. (2009) Ministry of Defence.

2. Sri Lanka Assesment (2012) South Asian Terrorism Portal.

3. Mathew K (1968) Objectivity, impartiality and good journalism. 14: 23-35.

4. Eytan G (2002) Media and conflict. (2ndedn), Ardsley: Transnational publishers.

5. Annabelle L, David B (2004) Reporting war: Grammar as covert operation. Pacific Journalism Review 10: 59-74.

6. Howard T, Frank W (2006) Journalists under fire. (1stedn), London: Sage Publications.

7. Wilson AJ (1998) The breakup of Sri Lanka: The Sinhalese Tamil conflict. Honalulu: University of Hawai Press.

8. Jayadeva U, Perera M (2003) Sri Lanka peace process2002: Critical perspectives. Colombo: Social Scientists Association.

9. Babara WF (1999) Designing Transition from Civil war: Demobilization, Democratization, and Commitments to Peace. International Security 24: 127. 